\title{
The study of thyroid profile in abnormal uterine bleeding at tertiary care center, Rajasthan, India
}

\author{
Dinesh Gurjar, Purnima Pachori*, Sandhya Chaudhary, Dharmendra Singh
}

Department of Obstetrics and Gynecology, JLN Medical College, Ajmer, Rajasthan, India

Received: 06 April 2019

Accepted: 06 May 2019

\section{*Correspondence:}

Dr. Purnima Pachori,

E-mail: drdineshrayana85@gmail.com

Copyright: (C) the author(s), publisher and licensee Medip Academy. This is an open-access article distributed under the terms of the Creative Commons Attribution Non-Commercial License, which permits unrestricted non-commercial use, distribution, and reproduction in any medium, provided the original work is properly cited.

\begin{abstract}
Background: Hypothyroidism and Hyperthyroidism leads to menstrual irregularities. Females with thyroid gland abnormality have chances of reproductive abnormalities ranging from abnormal sexual development, menstrual irregularities, infertility and premature menopause. The objectives were to study the association between thyroid dysfunction and AUB in the reproductive age group (18-45 years), To study the thyroid abnormalities in different types of AUB in the reproductive age group, to establish if screening for thyroid abnormalities is justified using T3, T4 and TSH.

Methods: This cross-sectional study conducted among 250 women with 'abnormal uterine bleeding' (AUB). Inclusion criteria for participants were females in the age group of 18-45 years, females presenting with abnormal uterine bleeding, with thyroid dysfunction, females who do not have signs of demonstrable pelvic pathologyincluding PID.

Results: Majority of the patients belonged to the age group of 24 - 32 years i.e.56.8\%, 9.2\% cases were nullipara, $44.0 \%$ cases have menorrhagia, 32.2\% have oliogomennorrhea, $19.6 \%$ have amenorrhea. Around $3.6 \%$ had Thyromegaly, $12.4 \%$ have weight gain in hypothyroidism, $28.4 \%$ have fatigue in hyperthyroidism, $6.8 \%$ cases have higher T4 level, $18.0 \%$ cases have higher TSH level.

Conclusions: The risk of progression to overt hypothyroidism (about 5\% per year) in patients with subclinical disease and the cost-benefit ratio also emphasises the need for selective screening. Early detection of subclinical disease by selective screening facilitates appropriate therapy early in the course of the disease.
\end{abstract}

Keywords: Abnormal uterine bleeding, Hypothyroidism, Hyperthyroidism, Menorrhagia, Oligomenorrhoea

\section{INTRODUCTION}

Thyroid gland plays important role in growth, development, metabolism and function of every organ in the body. ${ }^{1,2}$ Hypothyroidism and Hyperthyroidism leads to menstrual irregularities. Females with thyroid gland abnormality have chances of reproductive abnormalities ranging from abnormal sexual development, menstrual irregularities, infertility and prematuremenopause. ${ }^{3}$ Because of autoimmune nature of thyroid disorders, thyroid disorder prevalence is seen more among females. ${ }^{4}$
Incidence increases with age and its prevalence is $26 \%$ in women. ${ }^{5,6}$ Hypothyroidism even in subclinical form can cause menorrhagia. $^{2}$

The menstrual pattern is influenced by thyroid hormones directly through impact on the ovaries and indirectly through impact on SHBG, PRL and GnRH secretion and coagulation factors. Severe hypothyroidism is commonly associated with ovulatory dysfunction due to numerous interactions of thyroid hormones with the female reproductive system. Both hyperprolactinaemia, due to 
increased TRH production, and altered GnRH pulsatile secretion, leading to a delay in $\mathrm{LH}$ response and inadequate corpus luteum, have been reported. ${ }^{7-9}$ Thyroid responsivity by the ovaries could be explained by the presence of thyroid hormone receptors in humanoocytes. ${ }^{10}$ Thyroid hormones also synergize with the FSH mediated $\mathrm{LH} / \mathrm{hCG}$ receptor to exert direct stimulatory effects on granulosa cell function (progesterone production), and in in vitro studies effects on differentiation of the trophoblast have been shown. ${ }^{11,12}$ Another pathway through which hypothyroidism may impact on fertility is by altering the peripheral metabolism of oestrogen and by decreasing SHBG production. Both pathways may result in an abnormal feedback at the pituitary level. Independently of hormonal changes, hypothyroidism can also lead to menorrhagia by altered production of coagulation factors (decreased levels of factors VII, VIII, IX and XI). ${ }^{13}$

So, the study was conducted with the objectives to study the association between thyroid dysfunction and AUB in the reproductive age group (18-45 years), To study the thyroid abnormalities in different types of AUB in the reproductive age group, to establish if screening for thyroid abnormalities is justified using T3,T4 and TSH.

\section{METHODS}

This was a cross-sectional study conducted in Department of Obstetrics and Gynaecology, JLN Medical College and Hospital, Ajmer (Raj.) during Jan 2018 to Dec 2018 among the women with 'abnormal uterine bleeding' after ethical permission from Institutional Ethical Committee. Inclusion criteria for participants were females in the age group of 18-45 years, Females presenting with abnormal uterine bleeding, with thyroiddys function, Females who do not have signs of demonstrable pelvic pathology including PID and exclusion criteria were Patients who were pregnant, those who had an IUCD insertion, was known to have cervical or uterine malignancy, fibromyoma, polyp, etc, any coagulation disorders, liver/renal diseases or was on medications like steroids, neuroleptics, anticoagulants and cytotoxic drugs, etc. Study enrolled 250 women after applying inclusion and exclusion criteria. After taking a detailed history, including the menstrual and obstetric history, vitals was taken and systemic examination was done. Per abdomen examination, local examination, per speculum, per vaginum examination was done. Ultrasonography was done for all patients. Baseline investigations like $\mathrm{Hb}$, platelet count, TLC, DLC, RBS, S. Creat, BT, CT and PT was done. S.TSH, FT3 and FT4 by ELISA method was done. The data were recorded in an Excel sheet and descriptive analysis was performed, of which data are presented in the tables.

\section{RESULTS}

Table 1 shows $44.0 \%$ cases have menorrhagia, $32.2 \%$ have oliogomennorrhea, $19.6 \%$ have amenorrhea etc menstrual pattern. Most of the patients (87.6\%) presenting with $\mathrm{H} / \mathrm{O}$ abnormal uterine bleeding for less than one year. Majority of patients had normal BMI (18$24 \mathrm{~kg} / \mathrm{m} 2$ ) i.e. $71.6 \%$. Most of the patients who presented withs ymptoms of AUB had anemia $(\mathrm{Hb}<9 \mathrm{gm} \%)$ in $23.2 \%$ cases, while in most of the patients $61.6 \% \mathrm{Hb}$ was $>9$ and in $15.2 \%$ Hb cases estimation not done.

Table 1: Socio-clinical characteristics of study participants $(\mathrm{N}=\mathbf{2 5 0})$.

\begin{tabular}{|ll|}
\hline Variables & Number $(\%)$ \\
\hline Age & $32(12.8)$ \\
\hline $18-24$ & $142(56.8)$ \\
\hline $24-32$ & $51(20.4)$ \\
\hline $32-40$ & $25(10.0)$ \\
\hline$>40$ & \\
\hline Parity & $23(9.2)$ \\
\hline Nullipara & $227(90.8)$ \\
\hline Multipara & \\
\hline Type of AUB & $78(31.2)$ \\
\hline Oligomenorrhea & $110(44.0)$ \\
\hline Menorrhagia & $49(19.6)$ \\
\hline Amenorrhea & $7(2.8)$ \\
\hline Hypomenorrhea & $6(2.4)$ \\
\hline Polymenorrhea & \\
\hline Duration of AUB (in year) & $219(87.6)$ \\
\hline$>1$ & $23(9.2)$ \\
\hline $1-3$ & $8(3.2)$ \\
\hline$>3$ & \\
\hline BMI (wt in kg/ht in mt2) & $6(2.4)$ \\
\hline$<18$ & $179(71.6)$ \\
\hline $18-24$ & $48(19.2)$ \\
\hline $25-29$ & $17(6.8)$ \\
\hline$>29$ & $58(27.4)$ \\
\hline Hb (gm\%) (n=212) & $154(72.6)$ \\
\hline$<9$ & \\
\hline$\geq 9$ & \\
\hline & \\
\hline & \\
\hline & \\
\hline
\end{tabular}

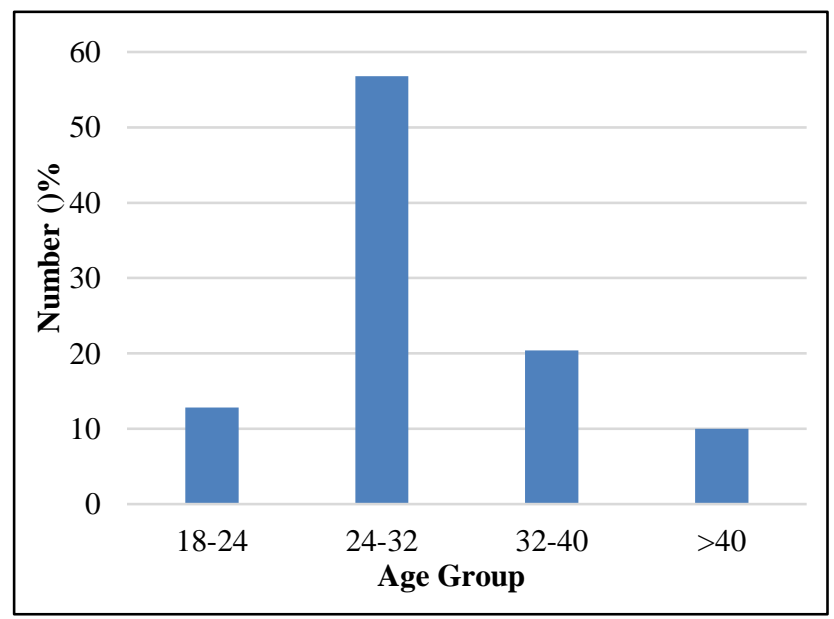

Figure 1: Age distribution among study participants $(\mathrm{N}=\mathbf{2 5 0})$. 
Table 1 and Figure 1 shows that majority of the patients belonged to the age group of $24-32$ years i.e. $56.8 \%$ followed by $32-40 y$ rs in it was $24.4 \%$.

Table 1 and Figure 2 shows that $9.2 \%$ participants were nullipara and $90.8 \%$ participants were multipara.

Table 2: Parameters related to thyroid gland among study participants $(\mathrm{N}=\mathbf{2 5 0})$.

\begin{tabular}{|c|c|}
\hline Parameter & Number $(\%)$ \\
\hline \multicolumn{2}{|l|}{ Thyroid Gland } \\
\hline Normal & $241(96.4)$ \\
\hline Thyromegaly & $9(3.6)$ \\
\hline \multicolumn{2}{|c|}{ Sign and symptoms of hypothyroidism } \\
\hline Nil & $176(70.4)$ \\
\hline Constipation & $19(7.6)$ \\
\hline Cold Intolerance & $1(0.4)$ \\
\hline Voice Change & $11(4.4)$ \\
\hline Weight Gain & $31(12.4)$ \\
\hline Lethargy & $12(4.8)$ \\
\hline \multicolumn{2}{|c|}{ Sign and symptoms of hyperthyroidism } \\
\hline Nil & $132(52.8)$ \\
\hline Heat Intolerance & $4(1.6)$ \\
\hline Anxiety & $12(4.8)$ \\
\hline Weight loss & $22(8.8)$ \\
\hline Restlessness & $71(28.4)$ \\
\hline Tremors & $6(2.4)$ \\
\hline Diarrhoea & $3(1.2)$ \\
\hline \multicolumn{2}{|l|}{ Serum T4 ( $\mu \mathrm{g} / \mathrm{dl})$} \\
\hline$<4.8$ & $34(13.6)$ \\
\hline $4.8-11.5$ & $199(79.6)$ \\
\hline$>11.5$ & $17(6.8)$ \\
\hline \multicolumn{2}{|l|}{ TSH } \\
\hline$<0.3$ & $23(9.2)$ \\
\hline $0.3-6.18$ & $182(72.8)$ \\
\hline$>6.18$ & $45(18.0)$ \\
\hline \multicolumn{2}{|c|}{ TSH level among cases of Amenorrhea $(n=49)$} \\
\hline$<0.3$ & $8(16.3)$ \\
\hline $0.3-6.18$ & $31(63.3)$ \\
\hline$>6.18$ & $10(20.4)$ \\
\hline \multicolumn{2}{|c|}{ TSH level among cases of Menorrhagia $(n=110)$} \\
\hline$<0.3$ & $0(0.0)$ \\
\hline $0.3-6.18$ & $88(80.0)$ \\
\hline$>6.18$ & $22(20.0)$ \\
\hline \multicolumn{2}{|c|}{ T4 level among cases of Oligomenorrhea $(n=81))$} \\
\hline$<4.8$ & $9(11.5)$ \\
\hline $4.8-11.5$ & $56(71.8)$ \\
\hline$>11.5$ & $13(16.7)$ \\
\hline
\end{tabular}

Table 2 shows that out of 250 patients $96.4 \%$ were having normal examination of Thyroid gland and $3.6 \%$ had Thyromegaly. Weightgain was the most frequent sign seen in $12.4 \%$ followed by constipation in $7.6 \%$, lethargy and voice change were seen in $4.8 \%$ and $4.4 \%$ respectively in the patient of hypothyroidism. The most common symptom was fatigue seen in $28.4 \%$, weight loss was seen in $8.8 \%$ cases followed by anxiety in $4.8 \%$ and tremors $2.4 \%$ in the patients of hyperthyroidism. Around $79.6 \%$ had normal T4 (4.8-11.5 $\mu \mathrm{g} / \mathrm{dl})$ level, $13.6 \%$ cases had T4 level less $<4.8 \mu \mathrm{g} / \mathrm{dl}$ and only $6.8 \%$ cases had T4 level above normal limit $>11.5 \mu \mathrm{g} / \mathrm{dl}$. Almost $72.8 \%$ patients had $\mathrm{TSH}$ level in normal range i.e. 0.3$6.18 \mu \mathrm{IU} / \mathrm{ml}$ and $9.2 \%$ had $\mathrm{TSH}<0.3$ i.e. corresponding to hyperthyroidism and $18 \%$ cases had TSH level above normal. Almost $20.41 \%$ patients of amenorrhea had TSH> 6.18 above the normal limit. Among the cases of menorrhagia, $20 \%$ were hypothyroid $\mathrm{TSH}>6.18 \mu \mathrm{IU} / \mathrm{ml}$ above the normal limit. $16.6 \%$ patients of oligomenorrhea had T4 value> $11.5 \mu \mathrm{g} / \mathrm{dl}$ above the normal limit which is corresponding hyperthyroidism.

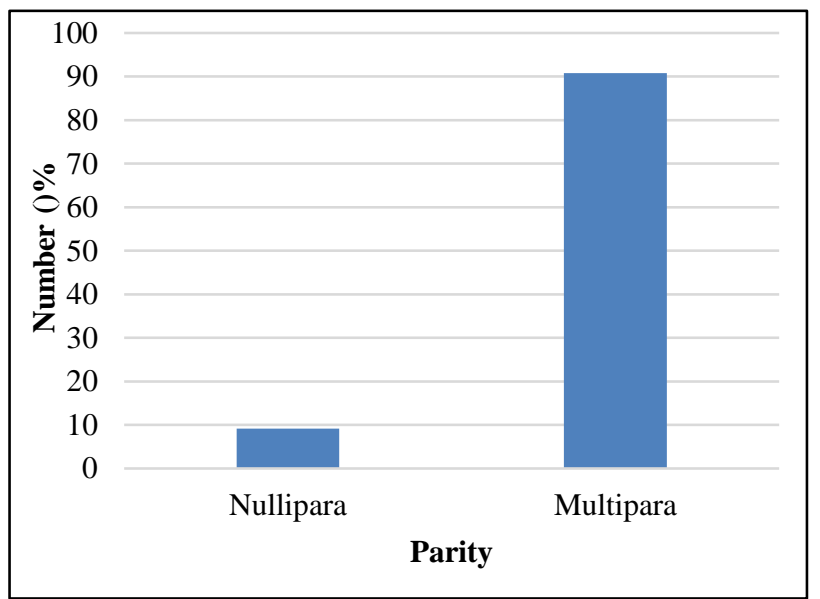

Figure 2: Parity distribution among study participants $(\mathrm{N}=\mathbf{2 5 0})$.

\section{DISCUSSION}

Thyroid diseases are more commonly seen among women with menstrual irregularities as compared to generalpopulation. ${ }^{14}$ Present study found the majority of patients belonged to age group of 24-32 years i.e. 56.8\% followed by $32-40$ years $(20.4 \%)$. Patients were less in extremes of ages. This finding correlates with the study done by Gollakota $\mathrm{S}$ et al, Gowri $\mathrm{M}$ et al, and Jinger SK et al. ${ }^{2,14,15}$ Present study included $90.8 \%$ multipara cases and this finding correlate with the study done by Komathi $\mathrm{R}$ et al, Gollakota $\mathrm{S}$ et al, and Gowri $\mathrm{M}$ et al. ${ }^{14,16,2}$ Present study observed most common menstrual pattern is menorrhagia i.e. $110(44 \%)$ followed by oligomenorrhoea in $78(31.2 \%)$, amenorrhoea in $49(19.6 \%)$, hypomenorrhoea $7(2.8 \%)$, polymenarrhoea $6(2.4 \%)$. This observations correlates with the study done by Gollakota S et al, Usharani $\mathrm{N}$ et al, and Ali J et al. ${ }^{2,17,18}$ In this prospective study of 250 AUB patients majority of patients had AUB duration for 1-3 months i.e. $38 \%$ followed by 4-6 months $(32.8 \%)$, only $2.4 \%$ cases had H/O AUB since menarche. Similar results were reported from study by Dr. Panda A et al. ${ }^{19}$

This study observed that $2.8 \%$ ) patients were euthyroid followed by 45 (18\%) patients were hypothyroid and 23 
(9.2\%) were hypothyroid. This finding is comparable with the study done by Gollakota $\mathrm{S}$ et al, and Pandey A et al. ${ }^{19}$ Hypothyroidism is observed in $8.8 \%$ of women with menorrhagia, and $4.0 \%$ of women with amenorrhea. Hyperthyroidism is seen in $5.6 \%$ of women with oligomenorrhea. The overall incidence of thyroid dysfunction is $20.4 \%$. This observation is correlated with the study done by Pennant ME et al, and Wilansky et al. $^{20,21}$

Alteration in the relationship between T4 and TSH can be caused by alternate thyroid stimulating hormones like TSH isoforms, chorionic gonadotrophins, and TSH receptor stimulating antibody. ${ }^{22}$

\section{CONCLUSION}

There is a significant association between thyroid disorders and AUB. The high incidence of thyroid disorders in women with AUB, particularly if the 7-10\% of subclinical hypothyroidism is included, justifies the cost of screening in this selective population. The risk of progression to overt hypothyroidism (about $5 \%$ per year) in patients with subclinical disease and the cost-benefit ratio also emphasises the need for selective screening. Early detection of subclinical disease by selective screening facilitates appropriate therapy early in the course of the disease.

Funding: No funding sources

Conflict of interest: None declared

Ethical approval: The study was approved by the Institutional Ethics Committee

\section{REFERENCES}

1. Olive D, Palter S. Reproductive Physiology.In: Berek J.S, eds. Berek and Novak's Gynaecology.14 th ed Philadelphia: Lippincott Williams and Wilkins Company; 2002:161-186.

2. Gollakota S, Nirmala CH, Naga AM. Study of Thyroid Profile in women with Abnormal Uterine Bleeding. IOSR J Dent Med Scien. 2017;16(10):536.

3. Thomas R. Reid RL. Thyroid diseases and reproductive dysfunction. Obstet Gynaecol. 1987;70:789-98.

4. Mazzaferri EL. Evaluation and management of thyroid disorders in women. Am J Obstet Gynaecol. 1997;176(3):144-9.

5. Kochupillai N. Clinical Endocrinology in India. Curr Sci. 2000;79:1061-7.

6. Hollowell JG, Staehling NW, Flanders WD. Serum T.S.H. T4 and Thyroid antibodies in the United States population. (1988 to 1994): National Health and Nutrition Examination Survey (NHANES III). J Clin Endocrinol Metab. 2002;87(2):489-99.

7. Longcope C, Abend S, Braverman LE, Emerson CH. Androstenedione and estrone dynamics in hypothyroid women. J Clin Endocrinol Metabol. 1990;70:903-7.

8. Scanlon MF, Chan V, Heath M, Pourmand M., Rodriguez-Arnao MD, Weightman DR, et al. and Hall R. Dopaminergic control of thyrotropin, alphasubunit, thyrotropin beta-subunit, and prolactin in euthyroidism and hypothyroidism: dissociated responses to dopamine receptor blockade with metoclopramide in hypothyroid subjects. J Clin Endocrinol Metabo. 1981;53:360-5.

9. Thomas R, Reid RL. Thyroid disease and reproductive dysfunction: a review. Obstet Gynecol. 1987;70:789-98.

10. Wakim AN. Polizotto SL, Buffo MJ, Marrero MA. Burholt DR. Thyroid hormones in human follicular fluid and thyroid hormone receptors in human granulosa cells. Fertility and Sterility. 1993;59:118790.

11. Cecconi S, Rucci N, Scaldaferri ML, Masciulli MP, Rossi G, Moretti C, et al. Thyroid hormone effects on mouse oocyte maturation and granulosa cell aromatase activity. Endocrinolo. 1999;140:1783-8.

12. Maruo T, Matsuo H, Mochizuki M. Thyroid hormone as a biological amplifier of differentiate dtrophoblast function in early pregnancy. Acta Endocrinol. 1991;125:58-66.

13. Ansell JE. The blood in the hypothyroidism. In: L. Braverman, R. Utiger eds. Werner and Ingbar's theThyroid: A Fundamental and Clinical Text. 7th Ed. Philadelphia: Lippincott-Raven; 1996:821-825.

14. Gowri M, Radhika BH, Harshini V, Ramaiaha R. Role of thyroid function tests in women with abnormal uterine bleeding. Int $\mathbf{J}$ Reprod Contracept Obstet Gynecol. 2014;3:54-7.

15. Jinger SK, Verma A, Dayma I, Talreja T. To study the thyroid profile in menstrual disorder at tertiary care hospital in northern western Rajasthan, India. Int J Res Med Sci. 2017;5:2212-4.

16. Komathi R, Mallika A. A study of thyroid profile in abnormal uterine bleeding (aub) among reproductive age group women. Int $\mathbf{J}$ Current Med Scie. 2016;6(7):133-6.

17. Usharani N, Shavi K. Clinical study of hypo/hyper thyroidism in dysfunctional uterine bleeding. Int $\mathbf{J}$ Reprod Contracept Obstet Gynecol. 2017;6:3324-7.

18. Ali J, Das KK, Konyak P. Study of relation of thyroid profile with abnormal uterine bleeding. Sch J App Med Sci. 2015;3:2688-92.

19. Panda A, Parulekar SV, Gupta A. Diagnostic hysteroscopy in abnormal uterine bleeding and histopathological correlation. J Obstet Gynaecol India. 1999;49:74-6.

20. Pennant ME, Mehta R, Moody P, Hackett G, Prentice A, Sharp SJ. Premenopausal abnormal uterine bleeding and risk of endometrial cancer. BJOG. 2017;124:404-11.

21. Wilansky DL, Grisesman B. Early hypothyroidism in patients with menorrhagia. Am J Obstet Gynaecol. 1990;163(2):697. 
22. Estrada JM, Soldin D, Buckey TM, Burman KD, Soldin OP. Thyrotropin Isoforms: Implications for Thyrotropin Analysis and Clinical Practice. Thyroid. 2014 Mar 1; 24(3): 411-23.
Cite this article as: Gurjar D, Pachori P, Chaudhary $\mathrm{S}$, Singh D. The study of thyroid profile in abnormal uterine bleeding at tertiary care center, Rajasthan, India. Int J Reprod Contracept Obstet Gynecol 2019;8:2429-33. 